\title{
Sustainable and responsible investment in Indonesia and Malaysia: an event study on SRI-KEHATI and FTSE4GBM Indices
}

\author{
Klara Petra Theodora Targanski*, Werner R. Murhadi
}

Faculty of Business and Economics, Universitas Surabaya, Surabaya, Indonesia

*Corresponding author: klara.targanski@gmail.com

\begin{abstract}
The purpose of this research is to examine the effect of SRI index on abnormal return of added to and deleted stocks of two countries, Indonesia (SRI-KEHATI) and Malaysia (FTSE4GBM). The effect was examined using CAAR of the stock around index announcement. This research was conducted using event study methodology. The samples used in this research are all the stocks that were added to and deleted from SRIKEHATI index on 2009-2018 announcements and FTSE4GBM index on 2014-2018 announcements. The result of hypothesis test shows that SRI index announcement has negative significant effect to the added stocks to SRI-KEHATI's CAAR before announcement, after announcement and cumulative periods, to added stocks to FTSE4GBM's before announcement and cumulative periods, and to deleted stocks from FTSE4GBM's after announcement and cumulative periods. SRI index announcements has positive significant effect to the deleted stocks from SRI-KEHATI's CAAR before announcement. Information on SRI index announcements has effects to the decisions made by investors. Indonesian investors reacted negatively toward added stocks but not choosing deleted stock either after announcements. Malaysian investors reacted negatively toward both added and deleted stocks, added stocks are perceived better even if positive CAAR are insignificant after announcements.
\end{abstract}

Keywords: abnormal return, CAAR, SRI index

JEL Classification Code: G11, G14, G40 DOI: $10.20885 /$ jsb.vol25.iss1.art6

\section{Introduction}

Sustainability concerns about three nonfinancial matters, which are environmental, social, and governance (ESG). Corporate social responsibility (CSR), sustainability report, and good corporate governance (GCG) are some of the parameters to assess ESG score of a company, especially listed companies (Williams, 2010). In financial sector, sustainable and responsible investment (SRI) is a financial product intended to make businessmen and investors responsible and profitable. SRI is also known as socially responsible investment.

SRI index is a product of cooperation between stock exchanges and institutions to be used as a guideline for stock portfolios to investors seeking for stocks with high ESG value and good financial performance. Sun et al. (2011) traced SRI indices from 1990-2011. American continent had the first SRI index, while Asian continent is the third continent to have index starting with Morningstar SRI index in Japanese Stock Exchange in 2003. In Indonesia, SRI-KEHATI was launched in 2009. Bursa Malaysia launched FTSE4Good Bursa Malaysia (FTSE4GBM) index in 2014.

SRI-KEHATI index was made by KEHATI Foundation and Indonesian Stock Exchange. The purpose of this index is to give alternative investment choices to Indonesian investors, especially in companies which are economically profitable and caring about environmental sustainability. In order to become this index constituent, the company will undergo two selection process, which are initial negative selection screening and the financial aspect as well as the testing of their fundamental aspect about the environment, governance, community involvement, business conduct, employment, and human rights. From selection review, 25 companies with the highest scores will be the index's constituents. 
Sustainable and responsible investment in Indonesia and Malaysia:

an event study on SRI-KEHATI and FTSE4GBM Indices

FTSE4GBM was made by FTSE Group and Malaysian Stock Exchange. This index is one of thematic indices in FTSE Bursa Malaysia. The constituents are chosen from FTSE BM EMAS constituents with screening in their ESG implementations. Beside the environment, social and governance aspects, there will be a negative selection screening too for tobacco, weapons, coal, and companies engaged in investment trusts. The scoring in nuclear power plants and baby milk and food will be more strict compare to other companies. If the company passes the screening, it will become one of the index's constituents.

These SRI indices re-evaluate their constituents regularly. For example, SRI-KEHATI and FTSE4GBM lists are updated every 6 months by issuing index announcements. The information from the announcement is expected to provide a positive signal for incoming companies and a negative signal for exit companies (Robinson et al., 2011). If the investors consider the index announcement as useful information, the price for added stocks to and deleted stocks from SRI index will be changed to the point of generating abnormal return.

Effects of the SRI index announcements will be examined on the added and deleted stocks. Attempts shall be carried out to find whether or not there is significant price change. In-previous studies, different countries and continents produced results which are consistent with the attitudes of investors in these countries and continents. Europe, according to Consolandi et al. (2008) and Ortas and Moneva (2011), has investors who are passionate about sustainability, where prices rose for added stocks to DJSI Stoxx index and prices fell for deleted stocks from DJSI Stoxx index. North American has a harsher reaction to stocks deleted from DJSI North America (Hayward, 2018) than to stocks deleted from DJSI World (Robinson et al., 2011). North American companies are expected not to leave DJSI North America while being in DJSI World counted as surplus. According to Cheung and Roca (2013), Asian still doesn't consider stocks added to SRI index as a good news. Investors also think that deleted stocks from SRI index is a bad news. As Indonesia and Malaysia are countries in Asia, their investors are very likely to have the same mindset as Asian investors at large, profit is foremost.

This research aims to answer research gap about Southeast Asian investors' attitude about sustainability, particularly about SRI indices in two countries which their SRI indices have been established for more than four years, Indonesia and Malaysia. By testing whether there is a cumulative average abnormal return (CAAR) on stocks added to and deleted from national SRI indices in Indonesia and Malaysia, it will be known whether the announcement of the SRI index is one of the information that influences investment decisions for investors in Indonesia and Malaysia.

\section{Literature Review}

\section{Efficient Market Theory Hypothesis}

According to Tandelilin (2017), efficient capital market is a market in which all traded securities reflect all available information. Fama (1970) states that there are three kinds of efficient market, which are weak-form efficient, semi-strong form efficient and strong form efficient. In weak-form market, all information in the past has been reflected in historical stock prices data, making it hard to use historical prices and to predict the current price. In semi-strong form market, all public information is readily available and stock prices adjust quickly to the information. In strong form market, the market is efficient and fully reflects both public and private information, and absorbs both the weak and semi-strong form.

Apart from being efficient in terms of information, the market also needs to be efficient in terms of decisions so that there are no abnormal returns. Investors need to analyze more before deciding to buy stocks, because the information needs to be understood in order to make the right decision about the stocks in the market. Fama (1991) divulge that the return estimation test is used for testing weak-form market efficiency, event studies are used for testing semi-strong form market efficiency and private information test for testing strong form market efficiency. 


\section{Event Study}

Event studies are used for testing semi-strong form market efficiency, as stated before. There is certain information that could make the stock market responsive and prices of related stocks fluctuated. Tandelilin (2017) mentions an event study as an investigation of market's response to the information content of an announcement or publication of certain events. The objective of the event study is to examine the market reaction in the period of observation on the price of securities around the time of the event (Peterson, 1989).

The purpose of an event study is to provide rationality in the market, that the effect of an event is immediately reflected in the price of securities in the capital market. There are 4 steps to conduct an event study, namely event definition, event criteria, calculating the rate of return and abnormal return, and testing the rate of abnormal return.

At the event definition stage, it is necessary to determine which event will be studied and the period of time to analyze the stock prices (event window). In this research, the event used is the regular announcements of constituents lists of SRI-KEHATI index and FTSE4GBM index with event window of 61 days, 20 days before and 40 days after the announcement, including the day of the announcement (event day).

Stage two would be determining and explaining the chosen event criteria. For example, company in the same industrial sector or being listed in the certain index. In this research, event criteria used are added stocks to and deleted stocks from SRI-KEHATI and FTSE4GBM indices.

Stage three is choosing one of the three methods to calculate returns and abnormal returns. They are the market model, the mean adjusted model and the market adjusted model. The type of data used is the time series because the observation time varies from one announcement to another. The next step is to test the abnormal return for the announcement day and cumulative abnormal return (CAR) for before and after the announcement day using t-test to know whether or not abnormal return and CAR occurs in the event window.

\section{Hypothesis Formation}

Based on previous studies about SRI indices announcements, different countries and continents produced results which are consistent with the attitudes of investors in these countries and continents. North American and European investors are rather keen to see the stocks to be added in the regional or the world SRI indices (Hayward, 2018; Robinson et al., 2011; Consolandi et al., 2008; Ortas and Moneva, 2011).

According to Cheung and Roca (2013), Asia as a whole was not quite receptive to SRI indices. Based on Nakai et al. (2012), Japanese investors changed their attitude toward stocks being listed in Morningstar-SRI index, they became receptive to added stocks in later years. Lee et al. (2019) show, Korean investors, especially pension funds managers, are very receptive to added stocks to DJSI World and DJSI Asia Pacific indices. It is still unknown how investors in other regions and nations of Asia react to stocks added to and deleted from to SRI index, but whether the country is an emerging country or a developed country will greatly influence the mindset of investors in that country.

Meanwhile, in Indonesia, Dewi and Oriana (2014) examined added stocks to SRI-KEHATI index in the period of 2009-2013 and found strong evidence of abnormal returns especially in ten days after the announcement. We follow their suggestion by using data from 2009-2018 and adding deleted stocks to the SRI-KEHATI samples. The data used in this study is added and deleted stocks on SRI-KEHATI index for the period of 2009-2018 and FTSE4GBM for the period of 2014-2018. Because Indonesia and Malaysia are categorized as emerging countries, the phenomenon here will be different than in developed country, where most of the previous researches were conducted. There are four hypotheses to be tested in this research:

H1: Stocks that were added to SRI-KEHATI index experience a negative price change.

$\mathrm{H} 2$ : Stocks that were deleted from SRI-KEHATI index experience a positive price change. 
H3: Stocks that were added to FTSE4GBM index experience a negative price change.

H4: Stocks that were deleted to FTSE4GBM index experience a positive price change.

\section{Methods}

This research is a basic research type because its function is to develop previous research and not to provide solutions to certain problems. The samples were selected by using purposive sampling. The samples in this research are added stocks to SRI-index in each announcement and deleted stocks from SRI index for each announcement. SRI-KEHATI samples were taken from announcements starts from October 2009 to April 2018. The FTSE4GBM samples were taken from announcement period of December 2014-December 2018. Table 1 shows the process of sample selection.

Table 1. Samples Selection, SRI KEHATI and FTSE4GBM

\begin{tabular}{|c|c|c|c|c|}
\hline & \multicolumn{2}{|c|}{ SRI KEHATI } & \multicolumn{2}{|c|}{ FTSE4GBM } \\
\hline & Added & Deleted & Added & Deleted \\
\hline Initial Sample & 450 & 23 & 293 & 9 \\
\hline Subtracts: Corporate Action & & & & \\
\hline Dividend announcements & 246 & 4 & 117 & 2 \\
\hline Stock Splits/Reverse Stock Splits & 1 & & & \\
\hline$M \& A$ & 7 & & 10 & \\
\hline Delisting & & & 1 & 1 \\
\hline Relisting & & & 1 & \\
\hline Divestitures & 1 & & & \\
\hline Name Change & & & 1 & \\
\hline Others & & & 5 & \\
\hline Total & 255 & 4 & 135 & 3 \\
\hline Subtracts: Unavailability of Data & 5 & & 3 & \\
\hline Subtracts: Auto-rejection (one of the CAR>50\%) & 2 & & 4 & \\
\hline Final Sample & 188 & 19 & 151 & 6 \\
\hline
\end{tabular}

As shown in Table 1, originally added stocks to SRI-KEHATI sample has 25 included stocks every announcement which results in a total of 450 stocks and deleted stocks from SRI-KEHATI sample has a total of 23 stocks from all announcements. In FTSE4GBM, added stocks sample change on each announcement, due to not having a fixed limit. Added stocks to FTSE4GBM has a total of 293 stocks from all announcements and deleted stocks from FTSE4GBM HAS a total of 9 stocks from all announcements. After subtracting the companies due to conducting corporate actions, unavailability of data, and auto-rejection, final samples are 188 stocks for added to SRIKEHATI, 19 stocks for deleted from SRI-KEHATI, 151 stocks for added to FTSE4GBM and 6 stocks for deleted from FTSE4GBM.

This data are in the form of daily share prices of companies added to and deleted from SRI indices and market index prices (JCI and FTSE BM EMAS) during the event window. The event window is divided into 4 parts, which are: before announcement period (pre-AD) from AD-20 to AD-1, announcement day (AD), after announcement period (post-AD) from $A D+1$ to $A D+40$, and all cumulative periods, both short and long term. Secondary data are taken from investing.com and duniainvestasi.com.

Data analysis begins by calculating the dependent variable, testing the hypothesis, and discussing the results of the research. The dependent variable in this research is CAAR. These are the steps required to obtain CAAR:

1. Calculation of the actual return

The actual return for each stock is calculated on daily basis during the event window period with the following formula: 


$$
\begin{aligned}
& \mathrm{R}_{\mathrm{it}} \quad=\ln \left(\frac{P_{i t}}{P_{i t-1}}\right) \\
& \mathrm{R}_{\mathrm{it}}=\text { Actual return of stock } i \text { on period } t \\
& P_{i t}=\text { Stock price in period } t \\
& P_{i t-}=\text { Stock price in period } t-1
\end{aligned}
$$

2. Calculation of the market return obtained from JCI and FTSE BM EMAS return Calculates the stock market return for each stock exchange (IDX and Bursa Malaysia). The daily market yield rate calculation is as follows:

$$
\begin{array}{ll}
\mathrm{R}_{\mathrm{mt}} & =\ln \left(\frac{I_{i t}}{I_{i t-}}\right) \\
\mathrm{R}_{\mathrm{mt}} & =\text { Stock market return on period } t \\
\mathrm{I}_{\mathrm{it}} & =\text { Closing stock market index on period } t \\
\mathrm{I}_{\mathrm{it}-1} & =\text { Closing stock market index on period } t-1
\end{array}
$$

3. The model used in this research is the market-adjusted model, causing the expected return is the stock market return $\left(E\left(R_{i t}\right)=R_{m t}\right)$. The daily abnormal return of each stock during the event window is the result of subtracting actual stock return with expected return, which is the stock market return. The formula is as follows:

$A R_{i t}=R_{i t}-\mathrm{E}\left(R_{i t}\right)$

$A R_{i \mathrm{t}}=$ Abnormal return stock $i$ on period $t$

$R_{i t} \quad=$ Actual return of stock $i$ on period $t$

$\mathrm{E}\left(\mathrm{R}_{\mathrm{it}}\right)=$ Expected return of stock $i$ on period $t$.

4. Calculates the CAR of each stock in accordance with each period's length. CAR is calculated using this formula:

CARt $_{1} t_{2}=\sum_{t 1}^{t 2} A R t$

$\mathrm{CAR}_{t 1 \mathrm{t} 2}=$ Cumulative abnormal return stock period $t_{2}$, which summation starts from abnormal return on period $t_{1}$

ARt $=$ Abnormal return on period $t$, from $t_{1}$ (period begins) to $t_{2}$ (period ends)

5. Categorizes the all the CAR per period to be tested and calculated for CAAR in the software. CAAR is calculated by this formula:

CAARt $=\frac{\sum_{i=1}^{k} \text { CARit }}{k}$

CAARt $=$ Cumulative average abnormal returns on period $t$

CARit $=$ Cumulative abnormal return of stock $i$ on period $t$

$\mathrm{k}=$ Number of stocks in the sample

\section{Result and Discussion}

\section{Result}

We provide the CAAR and the result of t-test in Table 2 for SRI-KEHATI index samples. The t-stat has significant negative values of one percent, five percent, and ten percent for the CAAR of the SRI-KEHATI's added stocks sample on short and long term periods, in the 5 days before announcement, as well as 10,20, and 40 days after announcement. The CAAR is not significant but negative in announcement day. For cumulative periods, the minimum CAAR is on [AD-10, AD+40] with value of -4.669 percent. As the significant t-stat values are in accordance to the hypotheses, hypotheses one is accepted.

The t-stat has significant positive value of five percent for the CAAR of SRI-KEHATI's deleted stocks sample on 20 and 10 days before announcement. The CAAR is not significant but negative in announcement day. There are negative CAARs after the announcement for the deleted stocks, but not significant. For cumulative periods, there wasn't any significant t-stat, whether positive or negative. As the significant t-stat values are in accordance to the hypotheses, hypotheses two is accepted. 
Table 2. One Sample T-test Results for Added Sample to and Deleted Sample from SRI-KEHATI Index

\begin{tabular}{|c|c|c|c|c|}
\hline & \multicolumn{2}{|c|}{ Added Sample $(\mathrm{N}=188)$} & \multicolumn{2}{|c|}{ Deleted Sample $(\mathrm{N}=19)$} \\
\hline Event window & CAAR & T-stat & CAAR & T-stat \\
\hline \multicolumn{5}{|c|}{ Before Announcement Effect: } \\
\hline [AD-20,AD-1] & $-0.007 \%$ & -0.012 & $5.884 \%$ & $2.781 * *$ \\
\hline$[\mathrm{AD}-10, \mathrm{AD}-1]$ & $-0.402 \%$ & -0.908 & $3.300 \%$ & $2.727 * *$ \\
\hline$[\mathrm{AD}-5, \mathrm{AD}-1]$ & $-0.501 \%$ & $-1.771 *$ & $0.198 \%$ & 0.233 \\
\hline \multicolumn{5}{|c|}{ Announcement Day Effect: } \\
\hline$A D$ & $-0.137 \%$ & -0.859 & $-0.076 \%$ & -0.291 \\
\hline \multicolumn{5}{|c|}{ After Announcement Effect: } \\
\hline Short term: & & & & \\
\hline$[\mathrm{AD}+1, \mathrm{AD}+5]$ & $-0.401 \%$ & -1.271 & $-0.221 \%$ & -0.238 \\
\hline$[\mathrm{AD}+1, \mathrm{AD}+10]$ & $-1.346 \%$ & $-2.861 * * *$ & $-0.704 \%$ & -0.514 \\
\hline \multicolumn{5}{|l|}{ Long term: } \\
\hline$[\mathrm{AD}+1, \mathrm{AD}+20]$ & $-2.280 \%$ & $-3.498 * * *$ & $-1.744 \%$ & -0.892 \\
\hline$[\mathrm{AD}+1, \mathrm{AD}+40]$ & $-4.131 \%$ & $-4.670 * * *$ & $-2.673 \%$ & -0.704 \\
\hline \multicolumn{5}{|c|}{ Cumulative Effect: } \\
\hline Short term: & & & & \\
\hline$[\mathrm{AD}-5, \mathrm{AD}+5]$ & $-1.039 \%$ & $-2.324 * *$ & $-0.099 \%$ & -0.096 \\
\hline$[\mathrm{AD}-10, \mathrm{AD}+10]$ & $-1.884 \%$ & $-2.924 * * *$ & $2.520 \%$ & 1.346 \\
\hline Long term: & & & & \\
\hline$[A D-10, A D+20]$ & $-2.819 \%$ & $-3.880 * * *$ & $1.480 \%$ & 0.695 \\
\hline$[\mathrm{AD}-10, \mathrm{AD}+40]$ & $-4.669 \%$ & $-4.972 * * *$ & $0.551 \%$ & 0.145 \\
\hline$[\mathrm{AD}-20, \mathrm{AD}+20]$ & $-2.424 \%$ & $-2.924 * * *$ & $4.064 \%$ & 1.619 \\
\hline$[\mathrm{AD}-20, \mathrm{AD}+40]$ & $-4.274 \%$ & $-4.240 * * *$ & $3.135 \%$ & 0.762 \\
\hline
\end{tabular}

Note: $* * *$, and $* * *$ denotes statistical significance at a $10 \%, 5 \%$, and $1 \%$ level

Table 3. One Sample T-test Results for Added Sample to and Deleted Sample from FTSE4GBM Index

\begin{tabular}{|c|c|c|c|c|}
\hline & \multicolumn{2}{|c|}{ Added Sample $(\mathrm{N}=151)$} & \multicolumn{2}{|c|}{ Deleted Sample $(\mathrm{N}=6)$} \\
\hline Event window & CAAR & T-stat & CAAR & T-stat \\
\hline \multicolumn{5}{|c|}{ Before Announcement Effect: } \\
\hline$[\mathrm{AD}-20, \mathrm{AD}-1]$ & $-1.597 \%$ & $-2.157 * *$ & $-4.731 \%$ & -1.849 \\
\hline$[\mathrm{AD}-10, \mathrm{AD}-1]$ & $-0.765 \%$ & $-1.819 *$ & $-4.242 \%$ & -1.8 \\
\hline$[\mathrm{AD}-5, \mathrm{AD}-1]$ & $-0.001 \%$ & -0.002 & $-1.948 \%$ & -1.149 \\
\hline \multicolumn{5}{|c|}{ Announcement Day Effect: } \\
\hline $\mathrm{AD}$ & $-0.039 \%$ & -0.293 & $0.714 \%$ & 0.423 \\
\hline \multicolumn{5}{|c|}{ After Announcement Effect: } \\
\hline Short term: & & & & \\
\hline$[\mathrm{AD}+1, \mathrm{AD}+5]$ & $-0.323 \%$ & -1.131 & $-1.918 \%$ & -0.869 \\
\hline$[\mathrm{AD}+1, \mathrm{AD}+10]$ & $-0.398 \%$ & -0.973 & $-0.254 \%$ & -0.113 \\
\hline \multicolumn{5}{|l|}{ Long term: } \\
\hline$[\mathrm{AD}+1, \mathrm{AD}+20]$ & $0.214 \%$ & 0.401 & $-2.623 \%$ & -1.679 \\
\hline$[\mathrm{AD}+1, \mathrm{AD}+40]$ & $0.669 \%$ & 0.912 & $-6.119 \%$ & $-4.139 * * *$ \\
\hline \multicolumn{5}{|c|}{ Cumulative Effect: } \\
\hline Short term: & & & & \\
\hline$[\mathrm{AD}-5, \mathrm{AD}+5]$ & $-0.363 \%$ & -0.748 & $-3.151 \%$ & -0.658 \\
\hline [AD-10,AD+10] & $-1.202 \%$ & $-1.894^{*}$ & $-3.782 \%$ & -0.73 \\
\hline Long term: & & & & \\
\hline [AD-10,AD+20] & $-0.589 \%$ & -0.87 & $-6.150 \%$ & -1.397 \\
\hline$[\mathrm{AD}-10, \mathrm{AD}+40]$ & $-0.135 \%$ & -0.161 & $-9.646 \%$ & $-2.466 *$ \\
\hline$[\mathrm{AD}-20, \mathrm{AD}+20]$ & $-1.422 \%$ & $-1.662 *$ & $-6.639 \%$ & -1.623 \\
\hline$[\mathrm{AD}-20, \mathrm{AD}+40]$ & $-0.968 \%$ & -1.01 & $-10.135 \%$ & $-2.661 * *$ \\
\hline
\end{tabular}


We provide the CAAR and the result of t-test in table 3 for FTSE4GBM index samples. There are significant negative t-stat values at five percent and ten percent for CAAR of added stocks to FTSE4GBM sample on two periods before announcement and 2 cumulative periods. Added stock has negative but insignificant CAAR on announcement day. Added stocks to FTSE4GBM has positive CAAR for the periods of 20 and 40 days after announcement, but t-stat values are insignificant. Cumulative periods CAARs are negative. Based on these results, hypotheses three is accepted.

There are significant negative t-stat values at one percent, five percent and ten percent for CAAR of deleted stocks to FTSE4GBM on one period after announcement and two cumulative periods. For the deleted stocks, CAAR is positive on the announcement day and negative on the other periods. Based on these results, hypotheses four is rejected.

\section{Discussion}

As seen in Table 2, CAAR of added stocks are all negative in every period, more than a half of t-stat values are significant. Significant negative test result before announcement showed that investors could guess the constituents of SRI-KEHATI, given financial and ESG company data were provided at company websites and reported by newspaper. Significant negative effect on added stocks has the same tendency with the CAAR of included stocks in research of Cheung and Roca (2013), even if their result is positive before announcement.

SRI-KEHATI has a fixed index constituents of 25. Those stocks whose assessments scores are slipping from top 25 will be deleted from SRI index list. CAAR of deleted stocks from SRIKEHATI turns negative starting from the announcement day, although not significant, indicates that there are investors who are avoiding risk. Chatzitheodorou et al. (2019) stated that some investors feared the outed companies have the potential for scandals related to governance, social, or environmental issues resulting in a decline in stock prices.

The ESG and SRI are not well-known in Indonesia, with the exception of CSR news in mass media, making included to SRI index is not what investors want. Investors in Indonesia saw additional efforts in non-profit making departments are mostly as additional costs, just like most of Asian investor thinks in Asia-Pacific region (Utz, 2017). Same thing happened to German companies that enter DJSI World in 1999-2002 in a research conducted by Oberndorfer et al. (2013). The CAAR was significantly negative in their research, same as in the SRI-KEHATI added stocks.

As seen in Table 3, there are changes in price, making the CAAR values for FTSE4GBM's added stocks become positive but significant CAAR values are all negative. The negative CAAR values are similar to SRI-KEHATI's result for the added stocks until 10 days after announcement. The positive but not significant CAAR values are similar to Lee et al. (2019) research for the added stocks to DJSI Korea. Given FTSE4GBM was launched at December 2014 and doesn't has a fixed limit for included constituents, the constituents are easy to guess, which promotes the significant CAAR before announcement.

The CAAR values of deleted stocks are negative. Consolandi et al. (2008) and Hayward (2018) found significant negative CAAR values for deleted stocks, as in the deleted stocks from FTSE4GBM index. Not many stocks were deleted from FTSE4GBM. FTSE and Bursa Malaysia continue to encourage stock exchange members to apply ESG principles on their companies, therefore, there is no limit to the number of FTSE4GBM constituents. The deleted stocks are not just bounce out from the ranking in the biannual assessment but they are having difficulty meeting the requirements to continue being constituents. This is a bad news to risk-averse investors.

Up to this date, sustainability is not a must in Bursa Malaysia. FTSE name has given the Malaysian SRI index enough influence, with CAAR values for added sample have some positive but insignificant t-stat and the CAAR values for deleted sample are significant negative. Risk-averse 
Sustainable and responsible investment in Indonesia and Malaysia:

an event study on SRI-KEHATI and FTSE4GBM Indices

investors are one of the reasons for the negative CAAR values for the deleted from the SRI index sample. This is consistent with the research of Albaity and Ahmad (2011) who found that on the SRI index, the bad news has greater effect than the good news.

\section{Conclusion}

SRI index announcement has negative significant effect on added stocks of SRI-KEHATI's CAARs, while the deleted stocks has positive significant effect on CAARs before announcement and insignificant negative effect on CAARs after announcement. Like the most of Asian investors, Indonesian investors still consider stocks being added to SRI index as a bad news but tend to be cautious to the deleted stocks.

For FTSE4GBM, added stock has negative significant effect on CAAR before announcement and insignificant positive effect on CAAR after announcement while the deleted stocks has negative significant effect on CAAR. Malaysian investors are more welcoming to SRI index, but not to the point where added stocks have significant positive effect on CAAR. The deleted stocks from FTSE4GBM were perceived by the market as bad news.

Investors in emerging countries like in Indonesia and Malaysia are skeptical about the implementation of ESG, making negative CAAR for added constituents to SRI index during announcement. The result of this research can be used as a reference for investors to consider in making the investment decisions, SRI index member stocks are good for long-term investments given they passed the financial screening. However, as they have up and down time, investor needs to choose the right time to buy and sell them. For company managers, we hope the result of this research would help them in making decisions both in a short-term and long-term company strategy regarding ESG in Indonesia and Malaysia.

This study has several limitations. First, the announcements are only checked for national SRI indices. For future researchers, they could examine Indonesian and Malaysian companies that are included and excluded in the international SRI index, like the DJSI Asia Pacific. Second, this study only studied abnormal return by using market-adjusted model. Future research can use other methods in calculating abnormal return and other variables like abnormal volume to examine. Third, how Indonesian and Malaysian investors view SRI index from the day of launching to the multiple years later. Future study can divide the sample to see the difference, for example by dividing sample to the first five years and the second five years for SRI index with more than ten years. Fourth, the difference between emerging country and developed country in SRI index. The differences in SRI indices between emerging and developed country can be fully explored in future study.

\section{Acknowledgements}

We thank Deddy Marciano and Endang Ernawati (Universitas Surabaya) for their comments on the manuscript.

\section{References}

Albaity, M. \& Ahmad, R. (2011). Return performance and leverage effect in Islamic and socially responsible stock indices evidence from Dow Jones (DJ) and Financial Times Stock Exchange (FTSE). African Journal of Business Management, 5(16): 6927-6939. DOI: 10.5897/AJBM10.1063

Chatzitheodorou, K., Sklouloudis, A., Evangelinos, K., \& Nikolaou, I. (2019) Exploring socially responsible investment prespective: A literature mapping and an investor classification. Sustainable Production \& Consumption, 19, 117-129. DOI: 10.1016/j.spc.2019.03.006 
Cheung, A. \& Roca, E. (2013). The effect of price, liquidity and risk when stocks are added to and deleted from a sustainability index: Evidence from the Asia Pacific context. Journal of Asian Economics, 24, 51-65. doi: 10.1016/j.asieco.2012.08.002

Consolandi, C., Jaiswal-Dale, A., Poggiani E., \& Vercelli, A. (2008). Global standards and ethical stock indexes: The case of the Dow Jones Sustainability Stoxx Index. Journal of Business Ethics, 87(1), 185-197. doi: 10.1007/s.10551-008-9793-1

Dewi, V. I. \& Oriana, F. (2014). Indeks SRI-KEHATI dan reaksi harga saham emiten terhadap pengumuman indeks SRI-KEHATI (Studi kasus pada indeks SRI-KEHATI). Research Report - Humanities and Social Studies, 2. Retrieved from http://journal. unpar.ac.id/index.php/Sosial/article/view/1225

Fama, E. (1970). Efficient capital markets: A review of theory and empirical work. Journal of Finance, 25(2), 383-417. DOI: 10.1111/j.1540-6261.1970.tb00518.x

Fama, E. (1991). Efficient capital markets: II. Journal of Finance, 46(5): 1575-1617. DOI: 10.1111/j.1540-6261.1991.tb04636.x

Hayward, L. (2018). Does the stock market value inclusion on a Sustainability Index? An event study using the Dow Jones Sustainability North America Index. Retrieved from Economics Department Student Scholarship. (https://crossworks.holycross.edu/econ_stu_scholarship/3)

Lee, S., Kim, I., \& Hong, C. (2019). Who value corporate social responsibility in the Korean stock market? Sustainability, 11(21), 5924. DOI: 10.3390/su11215924

Nakai, M., Yamaguchi, K., \& Takeuchi, K. (2012). Sustainability membership and stock price: An empirical study using the Morningstar-SRI index. Working Paper. Graduate School of Economics, Kobe University. Retrieved from: https://ideas.repec.org/ p/koe/wpaper/1204.html

Oberndorfer, U., Schmidt, P., Wagner, M., \& Ziegler, A. (2013). Does the stock market value the inclusion in a sustainability stock index? An event study analysis for German firms. Journal of Environmental Economics and Management, 66(3), 497-509. DOI: 10.1016/j.jeem.2013.04.005

Ortas, E. \& Moneva, J. M. (2011). Sustainability stock exchange indexes and investor expectations: Multivariate evidence from DJSI-Stoxx. Spanish Journal of Finance and Accounting, 4O(151), 395-416.

Peterson, P. P. (1989). Event studies: A review of issues and methodology. Quarterly Journal of Business and Economics, 28(3), 36-66.

Robinson, M., Kleffner, A., \& Bertels, S. (2011). Signaling sustainability leadership: Empirical evidence of the value of DJSI membership. Journal of Business Ethics, 101(3), 493-505. doi: 10.1007/s10551-011-0735-y

Sun, M., Nagata, K., \& Onoda, H. (2011). The investigation of the current status of socially responsible investment indices. Journal of Economics and International Finance, 3(13): 676684. DOI: $10.5897 /$ jeif.9000107

Tandelilin, E. (2017). Pasar modal manajemen portofolio dan investasi. Yogyakarta: PT Kanisius Yogyakarta. 
Utz, S. (2017). Over-investment or risk mitigation? Corporate social responsibility in Asia-Pacific, Europe, Japan and the United States. Review of Financial Economics. DOI: 10.1016/j.rfe.2017.10.001

Williams, G. (2010). Socially responsible investment in Asia. Social Space, 20-27. Retrieved from http://ink.library.smu.edu.sg/lien_research/62. 